результате автомобилисты и страховщики столкнулись с такими нюансами, как: иной механизм регулирования страховых случаев; международные нормы, отличные от российских; более высокий размер выплат потерпевшим; вопросы ценообразования страховых полисов «Зеленая карта» для отечественных автомобилистов; некий бюрократизм внутри страховщиков и недоверие со стороны страхователей. На сегодняшний день указанные проблемы затормаживают процесс адаптации данной страховой системы в России и наряду с пандемией откладывают срок интеграции России в мировом страховом пространстве.

Конечно, система международного автострахования имеет недостатки, но в России она существует немногим более 10 лет, поэтому, несмотря на начальную убыточность стоит продолжать в ней участвовать. По данным статистики, в сфере грузовых международных перевозок уже приходится 25-26 \% автомобильных перевозок, а значит - система востребована, это не говоря о том, что потоки автотуристов, пересекающих границы на личном транспорте, также увеличиваются.

Для решения проблем, думается, что на сегодняшний день необходимо развивать филиальные сети, занимающиеся международным автострахованием, повышать квалификацию персонала и качество обслуживания, заинтересованность потребителя выгодными предложениями, создать систему, когда цена страховых полисов будет достаточно устойчива и независима от колебаний валютного курса, предпринимать меры для устранения случаев мошенничества. Данные меры могут обеспечить рост в развитии системы страхования «Зеленая карта». Приобретение опыта правового урегулирования позволит не только расширить сферу услуг, но и защитить интересы российских граждан, попавших в сложную правовую ситуацию при ДТП за рубежом.

$$
* * *
$$

1. Об обязательном страховании гражданской ответственности владельцев транспортных средств: офиц. текст ФЗ от 25.04.2002 № 40-Ф3 // Собрание законодательства РФ. - 2002. - № 18. - Ст. 1720.

2. О национальном страховом бюро «Зеленая карта»: офиц. текст Распоряжения Правительства РФ от 19.03.2008 г. № 337-р // Собрание законодательства РФ. - 2008. - №12. - Ст. 1167.

3. Уведомление Министерства финансов РФ № 05-04-10/3К от 20.03.2008 г. // [Электронный ресурс]: сайт. - Режим доступа: https://autoins.ru/zelenaya-karta

4. Апелляционное определение Судебной коллегии по гражданским делам г. Ростов-на-Дону по делу № 33-7871/2018 от 07.05.2018 г. // [Электронный ресурс]: сайт. - Режим доступа: http://судебныерешения.pф/33983811/print

5. Решение Мурманского областного суда по делу № 2-1088/2014 от 12.08.2014 г. // [Электронный pecypc]: сайт. - Режим доступа: http://oblsud.mrm.sudrf.ru/modules.php

6. Российский Союз Страховщиков // [Электронный ресурс]: сайт. - Режим доступа: https://autoins.ru/zelenaya-karta/chto-takoe-zelenaya-karta/

7. Список стран - членов «Зеленой карты» // [Электронный ресурс]: сайт. - Режим доступа: https://www.cobx.org/article/45/gc-system-composed-green-card-bureaux-48-countries-participatingsystem

8. Юридическая помощь автомобилистам // [Электронный ресурс]: сайт. - Режим доступа: http://pravo-auto.com/

\title{
Бялт В.С., Чимаров С.Ю. \\ К вопросу о реализации конституционного права граждан Российской Федерации на равный доступ к государственной службе
}

Санкт-Петербургский университет МВД России (Россия, Санкт-Петербург)

doi: 10.18411/lj-04-2021-219

\section{Аннотация}

Статья посвящена исследованию особенностей реализации конституционного права российских граждан на равный доступ к государственной службе на примере поступления на службу в органы внутренних дел. Авторы, анализируя научную 
литературу и нормативную правовую базу в данной области, формулируют и обосновывают ряд выводов, касательно рассматриваемой проблематике.

Ключевые слова: конституционные права; государственная служба; органы внутренних дел; поступление на государственную службу.

\section{Abstract}

The article is devoted to the study of the features of the implementation of the constitutional right of Russian citizens to equal access to public service on the example of entering the service in the internal Affairs bodies. The authors, analyzing the scientific literature and the regulatory framework in this area, formulate and justify a number of conclusions concerning the problem under consideration.

Keywords: constitutional rights; public service; internal Affairs bodies; admission to public service.

Институт государственной службы на современном этапе административноправовой реформы в Российской Федерации занимает одно из ведущих мест в системе функционирования государственного механизма [6, с. 260]. Деятельность государственных служащих по исполнению различных функций государства направлена в первую очередь на совершенствование механизма реализации, охраны и защиты прав, свобод и законных интересов граждан. Тем не менее, процедура поступления на государственную службу сама связана с реализацией права граждан России на равный доступ к государственной службе, которое закреплено в Конституции Российской Федерации [1, ст. 32]. Однако не все граждане могут воспользоваться данным конституционным правом, поскольку существуют определенные ограничения, установленные действующими правовыми нормами. Таким образом, можно констатировать, что, исследование вопросов, связанных с реализацией права граждан на поступление на государственную службу, а также основаниями его ограничения, является весьма актуальным.

Система государственной службы в Российской Федерации включает в себя три вида государственной службы: государственная гражданская служба, военная служба, государственная служба иных видов [3, ст. 2].

Рассмотрим особенности реализации права граждан Российской Федерации на равный доступ к государственной службе на примере поступления на службу в органы внутренних дел.

Основными нормативными правовыми актами, регулирующими правоотношения в сфере поступления на службу в органы внутренних дел, являются Федеральный закон от 30 ноября 2011 года № 342 «О службе в органах внутренних дел Российской Федерации и внесении изменений в отдельные законодательные акты Российской Федерации» (далее - Закон о службе в органах внутренних дел) и Порядок организации прохождения службы в органах внутренних дел Российской Федерации, утвержденный Приказом МВД России от 1 февраля 2018 года № 50.

В рамках реализации конституционной нормы, допускающей возможность ограничения федеральным законом прав и свобод человека и гражданина в той мере, в какой это необходимо в целях защиты основ конституционного строя, нравственности, здоровья, прав и законных интересов других лиц, обеспечения обороны страны и безопасности государства [1, с. 55], нормативно определены случаи, когда гражданин не может быть принят на службу в органы внутренних дел $[4$, ст. 14,17$]$.

Исследуем такие основания ограничения в приеме на службу в органы внутренних дел как «осуждение гражданина за преступление по приговору суда, вступившему в законную силу, а равно наличие судимости, в том числе снятой или погашенной» и «выход из гражданства Российской Федерации».

В случае наличия у поступающего на службу судимости интересным для анализа представляется юридическая коллизия двух нормативных правовых актов, 
а именно с одной стороны Закона о службе в органах внутренних дел, а с другой стороны Уголовного кодекса Российской Федерации. Согласно нормам указанного кодекса «погашение или снятие судимости аннулирует все правовые последствия, связанные с судимостью» [2, ст. 86].

На практике встречаются случаи, когда кандидаты на службу в органы внутренних дел, имеющие погашенные судимости апеллируют к указанной норме и полагают, что их право на труд не может быть ограничено по данному основанию.

Разрешается же рассматриваемая коллизия следующим образом. И Закон о службе в органах внутренних дел, и Уголовный кодекс Российской Федерации по юридической силе равны - оба имеют статус федерального закона, но в данном случае будет действовать принцип приоритета специальной нормы над общей. По общему правилу для гражданина со снятой или погашенной судимостью все правовые последствия, связанные с ней должны быть аннулированы, но вот конкретно для поступления на службу в органы внутренних дел в отношении данного гражданина будет действовать уже специальная норма, не позволяющая ему поступить на службу. Мы полагаем, что это вполне справедливо, поскольку наличие такого ограничения способствует в определенной мере формированию кадрового состава органов внутренних дел из законопослушных граждан, не совершавших ранее преступлений. Иначе было бы не вполне понятным, как гражданин, совершивший преступление, осужденный судом, спустя некоторое время может сам быть представителем закона в государстве, по действиям которого другие граждане будут судить о состоянии правоохранительной системе в стране.

Выход из гражданства Российской Федерации как основание ограничения в приеме на службу в органы внутренних дел, с нашей точки зрения, является вполне обоснованным и логичным препятствием для реализации права поступления на государственную службу Российской Федерации. Если кандидат на службу планирует в дальнейшем защищать российские законы и требовать их соблюдения от других граждан, то он вне сомнения сам должен быть гражданином Российской Федерации. Однако, на наш взгляд, следует рассмотреть вопрос о возможности прохождения службы в органах внутренних дел лицами, имеющими двойное гражданство. Указанный тезис можно обосновать следующим образом:

1) согласно действующим нормам федерального законодательства в Российской Федерации «предусматривается поступление иностранных граждан на военную службу по контракту и прохождение ими военной службы» [3, ст. 18.1];

2) анализ зарубежного опыта показывает, что в некоторых странах нормативно определена возможность прохождения правоохранительной службы сотрудниками, имеющими двойное гражданство [5, с. 121];

3) по нашему мнению, обозначенное положение позволит осуществлять выбор кандидатов из большего числа претендентов, что в свою очередь будет косвенно способствовать повышению качественного состава кадров органов внутренних дел [7, с. 114].

Обобщая все вышеизложенное, можно сформулировать следующие выводы:

- исследование вопросов, касающихся реализации конституционного права граждан Российской Федерации на поступление на государственную службу, а также оснований его ограничения, имеет важнейшее значение в аспекте анализа и обобщения имеющихся знаний в области института прав человека;

- право граждан на равный доступ к государственной службе закреплено в Конституции Российской Федерации, однако нормами федерального законодательства установлены определенные ограничения для поступления на конкретный вид государственной службы;

- существование указанных ограничений обосновывается тем, что эффективная реализация государственными органами своих 
функций предполагает наличие кадрового состава государственных служащих, отвечающего современным повышенным требованиям.

1. Конституция Российской Федерации: (принята всенародным голосованием 12 декабря 1993 года с изменениями, одобренными в ходе общероссийского голосования 1 июля 2020 года) // Российская газета. 1993. 25 декабря; СЗ РФ. 2020. № 11. СТ. 1416.

2. Уголовный кодекс Российской Федерации от 13 июня 1996 года № 63-Ф3 (в ред. от 24 февраля 2021 года) // СЗ РФ. 1996. № 25. Ст. 2954; 2021. № 9. Ст. 1472.

3. Федеральный закон от 27 мая 2003 года № 58-Ф3 «О системе государственной службы Российской Федерации» (в ред. от 23 мая 2016 года) // С3 РФ. 2003. № 22. Ст. 2063; 2016. № 22. Ст. 3091.

4. Федеральный закон от 30 ноября 2011 года № 342 «О службе в органах внутренних дел Российской Федерации и внесении изменений в отдельные законодательные акты Российской Федерации» (в ред. от 8 декабря 2020 года) // СЗ РФ. 2011. № 49. Ч. 1. Ст. 7020; 2020. № 50. Ч. 3. Ст. 8074.

5. Ёркина Т. Н. Полиция в России и зарубежных странах. Вопросы кадровой политики, деятельности и реформирования // Закон и право. 2019. № 6. С. 119-122.

6. Корзанова А. В. Государственная служба на современном этапе в России // Трибуна ученого. 2020. № 11. C. 260268.

7. Первитская А. М. Профессионально-психологический отбор кандидатов на службу в органы внутренних дел Российской Федерации // Вестник Ярославского государственного университета им. П. Г. Демидова. Серия гуманитарные науки. 2020. № 4 (54). С. 110-115.

\section{Бялт В.С., Чимаров С.Ю. \\ К вопросу о методологии теории государства и права}

Санкт-Петербургский университет МВД России (Россия, Санкт-Петербург)

doi: 10.18411/lj-04-2021-220

\section{Аннотация}

Статья посвящена исследованию системы методов научного познания в рамках рассмотрения такой основополагающей фундаментальной юридической науки как теория государства и права. Авторы, анализируя существующие подходы ученых правоведов к методологии юридической науки, обобщают их мнения, а также формулируют и обосновывают собственные выводы касательно исследуемых вопросов.

Ключевые слова: теория права; теория государства; методология; наука; научное познание.

\section{Abstract}

The article is devoted to the study of the system of methods of scientific knowledge in the framework of consideration of such a fundamental fundamental legal science as the theory of state and law. The authors analyze the existing approaches of legal scholars to the methodology of legal science, summarize their opinions, as well as formulate and justify their own conclusions regarding the issues under study.

Keywords: theory of law; theory of state; methodology; science; scientific knowledge.

Все возрастающий объем научных знаний повышает требования к точности, строгости, логической последовательности научного мышления, а это с необходимостью предполагает изучение самого познавательного процесса. Без такого изучения невозможно не только овладеть той огромной массой знаний, которые уже накоплены человечеством, но и осуществлять дальнейшее, более всестороннее и углубленное проникновение в тайны исследуемых объектов, явлений и процессов [2, c. 8-9]. Не случайно В. М. Сырых разработку проблем методологии правовой науки выделяет как самостоятельное направление научных исследований метатеоретических исследований [9, с. 16]. Теория государства и права выступает фундаментальным основополагающим звеном системы правовых знаний, и сама формирует и описывает комплекс методов познания государственно-правовых явлений. 